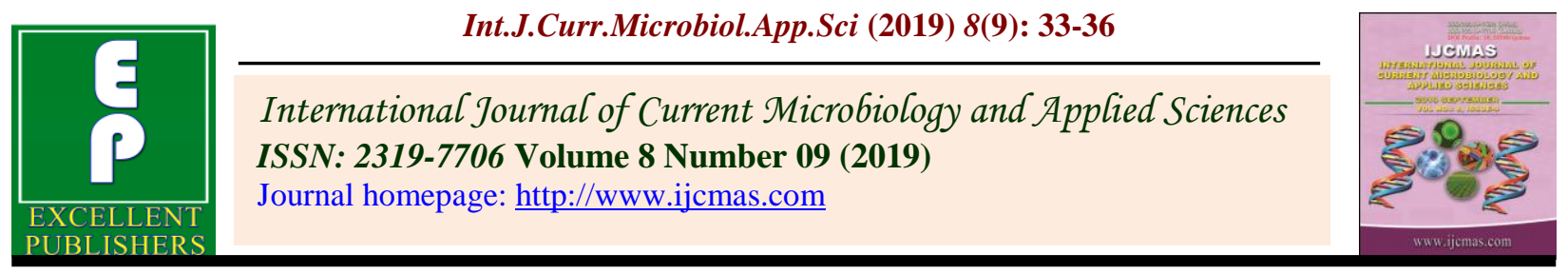

Original Research Article

https://doi.org/10.20546/ijcmas.2019.809.005

\title{
Performance of Rice Cultivars under Different Methods of Tillage Operation
}

\author{
Naba Kishore Mahato ${ }^{1 *}$, Dibyendu Mukhopadhyay ${ }^{2}$ and Debasis Mahata $^{3}$ \\ ${ }^{1}$ RRS, Old Alluvial Zone, Uttar Banga Krishi Viswavidyalaya, Majhian, Patiram, Dakshin \\ Dinajpur-733133, West Bengal, India \\ ${ }^{2}$ Department of Soil Science and Agricultural Chemistry, Uttar Banga Krishi Viswavidyalaya, \\ Pundibari, Cooch Behar, West Bengal-736165, India \\ ${ }^{3}$ Agronomy, Uttar Dinajpur Krishi Vigyan Kendra, Chopra, Islampur, Uttar Dinajpur- \\ 733207, West Bengal, India \\ *Corresponding author
}

A B S T R A C T

\begin{tabular}{|c|}
\hline Keywords \\
\hline $\begin{array}{l}\text { Rice, SRI, } \\
\text { conventional, Grain } \\
\text { yield, Soil moisture }\end{array}$ \\
\hline Article Info \\
\hline $\begin{array}{l}\text { Accepted: } \\
04 \text { August } 2019 \\
\text { Available Online: } \\
\text { 10 September } 2019\end{array}$ \\
\hline
\end{tabular}

\section{Introduction}

Rice in India contributes about $65 \%$ of the total food grain production. About $45 \mathrm{~m}$-ha area is under rice cultivation of this about $22.5 \mathrm{~m}$-ha area of the country is under irrigation and $38 \%$ of the rice growing area comprises rain fed shallow low land and deep water areas. The country's rice production declined to 89.13 million tonnes in 2009-10
A field experiment was conducted during 2011-2012 at the Instructional farm, Uttar Banga Krishi Viswavidyalaya pundibari, Cooch Behar, West Bengal during the Boro season to find out the effect of grain yield of rice cultivars under different methods of rice cultivation (SRI and conventional) at a given soil moisture content. The yield attributes of rice among the different varieties (Pioneer, RH664, Lalat and GB-1) in both SRI and conventional systems were recorded. The maximum yield $\left(5.02 \mathrm{t} \mathrm{ha}^{-1}\right)$ in RH664 under SRI over the other was observed, while maximum yield (3.41 $\mathrm{t} \mathrm{ha}^{-1}$ ) for GB-1 was observed under the conventional method of cultivation. The maximum straw yield of $4.55\left(\mathrm{t} \mathrm{ha}^{-1}\right)$ in GB-1 under SRI over the other was observed, while the straw yield of $3.67 \mathrm{t} \mathrm{ha}^{-1}$ in GB-1 was observed under the conventional method of cultivation. 
rice. The variable soil properties can influence the yield of the crop for a particular variety. Based on the above perspectives, the present study was under taken to find out the performance of different rice cultivars in terms of the yield of the crop at different tillage operations. It has been observed that our national food security hangs on the growth and stability of rice production. India has the largest acreage under rice of about 44.6 million hectares of land under four major ecosystems viz. irrigated (46\%), rainfed lowland (28\%), rainfed upland (12\%) and flood prone (14\%), which occupies 21,14,6 and 3 million hectare respectively, with a production of about 90 million tonnes (Siddiq, 1999)

\section{Materials and Methods}

The field experiments were carried out at the Instructional farm, Uttar Banga Krishi Viswavidyalaya, Pundibari, Cooch Behar, West Bengal, India during 2012 in the Boro season. The farm is situated at $26^{0} 19^{\prime} 86^{\prime \prime} \mathrm{N}$ latitude and $89^{\circ} 23^{\prime} 53^{\prime}$ ' $\mathrm{E}$ longitude and at an elevation of 43 meter above the mean sea level. The northern region of West Bengal (Terai zone) is placed along Kalimpong hills, Kurseong hills and Bhutan hills in northern side. The soil is sandy loam, (61-63\% sand, $20 \%$ silt and 16-18\% clay) in texture. Different rice cultivars; Pioneer, RH-664, Lalat and GB-1 were grown under the SRI and Conventional methods of tillage. The seedlings were transplanted with a spacing of $8 \mathrm{~cm} \times 6 \mathrm{~cm}$ in conventional methods and seedlings were transplanted with a spacing of $10 \mathrm{~cm} \times 10 \mathrm{~cm}$ at a depth of $1.5 \mathrm{~cm}$ in SRI. The unit plot size was $5 \mathrm{~m} \times 3 \mathrm{~m}$. The mean maximum temperature varied from 29.6 to $42.1^{\circ} \mathrm{C}$ and the mean minimum temperature varied from 16.6 to $27.3^{\circ} \mathrm{C}$. No rains were received during the crop growth period. First weeding was done 12 days after transplanting and thereafter weeding was done once in every 10 days with the help of paddy weeder and simultaneously the weeds were incorporated. The observations on tillering pattern were taken at periodical interval, while the observation on yield attributes as well as yield were recorded accordingly. Seedlings were raised in the nursery bed. In SRI method of cultivation, 10 days old seedlings were transplanted in the main field with one seedling per hill and one month old seedlings were transplanted in conventional method of cultivation. A fertilizer dose of $\mathrm{N}: \mathrm{P}: \mathrm{K}=$ $80: 40: 40 \mathrm{~kg}$ per ha was given as per the recommended package of practice. Fertilizers were given in the form of urea, DAP and MOP in the respective treatments. The System of Rice Intensification (SRI) was recently introduced into India and slowly gaining momentum since 2003. If SRI is to be applied with the water now being used for rice irrigation, it would be able to increase irrigated area by at least 50 per cent, leading to 50 per cent increase in rice production (Thakkar, 2005).

\section{Results and Discussion}

Soil moisture content with different depth under SRI and Conventional System depth (0-15cm)

The available soil moisture content (Table 1) at $0-15 \mathrm{~cm}$ depth of soil showed significant variation at different growth period of rice grown under two different methods of cultivation (i.e. SRI and Conventional). The soil moisture at the saturation and submerged conditions in respect to the different growth period of rice was measured. In general the available moisture content in soil at submergence was higher over the saturation of soil during 100 to 120 DAT under both the SRI and Conventional methods of cultivation for all the selected varieties. 
Table.1 Soil moisture content with different depth under SRI and conventional system depth $(0-15 \mathrm{~cm})$

\begin{tabular}{|c|c|c|c|c|c|c|c|c|c|c|c|c|c|c|}
\hline \multirow[t]{2}{*}{ Sl. No. } & \multirow[t]{2}{*}{ Depth (cm) } & \multirow{2}{*}{$\begin{array}{l}\text { Initial } \\
\text { Saturation }\end{array}$} & \multicolumn{2}{|l|}{20 DAT } & \multicolumn{2}{|c|}{40 DAT } & \multicolumn{2}{|c|}{60 DAT } & \multicolumn{2}{|c|}{80 DAT } & \multicolumn{2}{|c|}{100 DAT } & \multicolumn{2}{|c|}{120 DAT } \\
\hline & & & Saturation & $\begin{array}{l}\text { Submer } \\
\text { ged }\end{array}$ & $\begin{array}{l}\text { Satur } \\
\text { ation }\end{array}$ & $\begin{array}{l}\text { Submer } \\
\text { ged }\end{array}$ & $\begin{array}{l}\text { Satur } \\
\text { ation }\end{array}$ & $\begin{array}{l}\text { Submer } \\
\text { ged }\end{array}$ & $\begin{array}{l}\text { Satur } \\
\text { ation }\end{array}$ & $\begin{array}{l}\text { Submer } \\
\text { ged }\end{array}$ & $\begin{array}{l}\text { Satur } \\
\text { ation }\end{array}$ & $\begin{array}{l}\text { Submer } \\
\text { ged }\end{array}$ & $\begin{array}{l}\text { Satur } \\
\text { ation }\end{array}$ & $\begin{array}{l}\text { Submer } \\
\text { ged }\end{array}$ \\
\hline M1V1 & $(0-15)$ & 39.66 & 42.76 & 48.87 & 44.08 & 38.53 & 42.34 & 35.87 & 42.90 & 41.69 & 39.35 & 51.89 & 41.17 & 45.05 \\
\hline M1V2 & $(0-15)$ & 39.31 & 40.27 & 48.43 & 44.24 & 35.39 & 42.27 & 34.78 & 37.88 & 52.84 & 41.90 & 48.31 & 43.27 & 63.34 \\
\hline M1V3 & $(0-15)$ & 40.13 & 39.23 & 46.69 & 40.98 & 33.89 & 40.98 & 31.69 & 41.05 & 46.21 & 40.57 & 56.89 & 41.36 & 53.48 \\
\hline M1V4 & $(0-15)$ & 40.18 & 41.04 & 48.74 & 40.70 & 27.63 & 44.09 & 32.26 & 36.47 & 33.13 & 40.89 & 55.29 & 40.00 & 38.44 \\
\hline M2V1 & $(0-15)$ & 40.41 & 37.31 & 46.29 & 39.60 & 26.23 & 38.03 & 36.08 & 42.18 & 47.81 & 35.65 & 42.83 & 42.23 & 53.25 \\
\hline M2V2 & $(0-15)$ & 38.12 & 40.00 & 48.11 & 42.80 & 35.14 & 45.61 & 33.86 & 38.21 & 42.00 & 42.48 & 46.61 & 43.83 & 46.21 \\
\hline M2V3 & $(0-15)$ & 36.92 & 32.89 & 42.12 & 43.89 & 32.54 & 40.04 & 35.67 & 38.35 & 52.53 & 42.33 & 42.56 & 40.24 & 52.74 \\
\hline M2V4 & $(0-15)$ & 37.36 & 33.53 & 46.62 & 42.96 & 42.33 & 37.55 & 35.87 & 41.33 & 41.04 & 42.89 & 54.71 & 38.34 & 45.70 \\
\hline \multicolumn{2}{|c|}{ CD Value (5\% Level) } & $1.20 *$ & $2.02 *$ & $1.85^{*}$ & $1.53^{*}$ & $1.23^{*}$ & $1.26^{*}$ & $1.65^{*}$ & $2.90 *$ & $1.49^{*}$ & $2.51 *$ & $1.65^{*}$ & $3.16^{*}$ & $8.47 *$ \\
\hline \multicolumn{2}{|c|}{ SEm \pm} & 0.39 & 0.65 & 0.60 & 0.49 & 0.40 & 0.40 & 0.53 & 0.94 & 0.48 & 0.81 & 0.53 & 1.02 & 2.75 \\
\hline
\end{tabular}

DAT = Day after Transplanting, $\mathrm{M}_{1}=\mathrm{SRI}$ Method, $\mathrm{M}_{2}=$ Conventional Method, Star $=$ Significant, $\mathrm{V}_{1}-\mathrm{Pioneer}_{2} \mathrm{~V}_{2}-\mathrm{RH}-664, \mathrm{~V}_{3}-\mathrm{Lalat}_{\text {and }} \mathrm{V}_{4}-\mathrm{GB}-1$

Table.2 Yield component of rice cultivars under SRI and conventional methods

\begin{tabular}{|c|c|c|c|c|c|}
\hline \multicolumn{6}{|c|}{ Yield attributes } \\
\hline Treatment & $\begin{array}{l}\text { Panicle length } \\
\qquad\left(\mathrm{cm} \mathrm{m}^{-2}\right)\end{array}$ & $\begin{array}{c}\text { Total } \\
\left(\text { hill }^{-1} \mathbf{m}^{-2}\right)\end{array}$ & $\begin{array}{l}\text { Number of tiller } \\
\quad\left(\text { hill }^{-1} \mathbf{m}^{-2}\right)\end{array}$ & $\begin{array}{c}\text { Yield } \\
\left(\mathrm{g} \mathrm{m}^{-2}\right)\end{array}$ & $\begin{array}{c}\text { Yield (q } \\
\left.\text { ha }^{-1}\right)\end{array}$ \\
\hline$M_{1} V_{1}=S R I+$ Pioneer & 24.93 & 13.67 & 10.33 & 320.37 & 48.07 \\
\hline$M_{1} V_{2}=S R I+R H-664$ & 25.59 & 12.67 & 9.53 & 322.87 & 50.17 \\
\hline$M_{1} V_{3}-$ SRI+Lalat & 24.86 & 13.33 & 10.07 & 273.84 & 45.15 \\
\hline$M_{1} V_{4}=S R I+G B-1$ & 22.07 & 19.67 & 9.00 & 336.90 & 40.71 \\
\hline $\mathbf{M}_{2} \mathbf{V}_{1}=$ Conventional + Pioneer & 23.87 & 14.33 & 9.73 & 474.55 & 32.29 \\
\hline$M_{2} V_{2}=$ Conventional +RH 664 & 25.17 & 14.67 & 9.80 & 490.24 & 33.14 \\
\hline $\mathbf{M}_{2} \mathbf{V}_{3}=$ Conventional +Lalat & 23.18 & 17.33 & 10.33 & 456.22 & 27.60 \\
\hline $\mathbf{M}_{2} \mathrm{~V}_{4}=$ Conventional +GB -1 & 19.54 & 28.00 & 11.13 & 399.97 & 34.05 \\
\hline CD Value (5\% Level) & 1.71 & 4.45 & 2.64 & 84.92 & $0.41 *$ \\
\hline SEm \pm & 0.56 & 1.45 & 0.86 & 27.56 & 0.13 \\
\hline
\end{tabular}


Similarly, Ceesay and Uphoff (2003) reported that the water management practice proposed for the systems of rice intensification (SRI), cycles of repeated wetting and drying were found beneficial to rice plant growth though increased nutrient availability leading ultimately to high grain. The available soil $\mathrm{N}$ did not vary significantly between SRI and Conventional method at 20,40,60,80,100 and 120 DAT. At 100 DAT and at harvest, SRI method recorded significantly higher available $\mathrm{N}$ than Conventional method. It might be due to higher $\mathrm{N}$ loss under Conventional method through denitrification and leaching.

\section{Yield attributes under SRI and Conventional system of Boro rice}

The yield attributes and yield of rice (Table 2) showed the significant yield difference among the varieties in both SRI and Conventional systems and maximum yield $(50.17 \mathrm{q} / \mathrm{ha})$ in RH664 under SRI over the other was observed, while maximum yield (34.05 q/ha) for GB-1 was observed under the conventional method of cultivation. Similarly the straw yield of rice showed significant difference among both the systems under SRI and Conventional and maximum straw yield 45.48 (q/ha) in GB-1 under SRI over the other was observed, while maximum straw yield
(36.76 q/ha) in GB-1 was observed under the conventional method of cultivation.

The straw yield also followed the similar trend as that of grain yield. It has been reported that the increase grain and straw yield by increasing $\mathrm{N}$ levels from 40-120 $\mathrm{kg} / \mathrm{ha}$ brought about significance increase of grain yield and straw yield, Kumar et al., (2000).

\section{References}

Ceesay M. and Uphoff, N. (2003). The effects of repeated soil wetting and drying on lowland rice yield with System of Rice Intensification (SRI) methods. In: http://ciifad.cornell.edu/.

Kumar, P., Mutanal, S. M., Joshi, V. R. and Prabhakar, A. S. (2000). Response of rice (Oryza sativa) to urea form and nitrogen level under transplanted condition. Indian Journal of Agricultural Sciences, 67(12): 554-556.

Siddiq, E. A. (1999). Not a distant dream. The Hindu Survey of Indian Agriculture, pp. 39-47.

Thakkar, H., (2005). More rice for less water. Info change News and Features, June 2005.

In: http://www.infochangeindia.org.

\section{How to cite this article:}

Naba Kishore Mahato, Dibyendu Mukhopadhyay and Debasis Mahata. 2019. Performance of Rice Cultivars under Different Methods of Tillage Operation. Int.J.Curr.Microbiol.App.Sci. 8(09): 33-36. doi: https://doi.org/10.20546/ijcmas.2019.809.005 